\title{
Farmer's Pensions as an Instrument of Changing the Agrarian Structure in Poland
}

\author{
Pawel Pięta \\ PhD Candidate, Warsaw University of Life Sciences, SGGW, Poland
}

\begin{abstract}
The pace of structural changes in Polish agriculture is slower than in other European Union countries. At the same time, it should be noted that this process in various provinces is also diversified. The reasons for this are, among others, the historical, social and economic conditions of individual regions. To accelerate this process, structural policy measures have been introduced that would foster land concentration and farm enlargement. This was to be served by the structural pensions scheme for farmers - one of the measures of the Rural Development Plan for 2004-2006 and the Rural Development Program for the years 2007-2013.
\end{abstract}

The program was intended to encourage farmers to stop agricultural activities in the pre-retirement age and to transfer their farms in a way that would improve the area structure of farms in Poland and reduce their number. This measure was intended to also contribute to the improvement of the viability of agricultural holdings in Poland and to provide a sufficient source of income for farmers who cease farming. The expected effect of the structural pensions scheme is changes in the area structure of agricultural holdings, which will contribute to the reduction of farm fragmentation, as well as to the re-qualification of a part of under-utilized agricultural land for non-agricultural purposes. Due to the assumed objective of the action, as well as the economic effectiveness of the funds spent, in the RDP for the years 2007-2013, it was decided to tighten the access criteria in relation to this action compared to the previous programming period. The extent to which Poland's countryside benefits from integration with the European Union will affect the prospects for its development for many decades. Instruments implemented under the RDP for the years 2004-2006 and RDP for the years 2007-2013 were to facilitate the modernization of agriculture, and hence to ensure sustainable development of rural areas. The process of changes in the countryside is not limited to transformations in agriculture itself, but above all to changes in its surroundings.

Keywords: farmer's pensions, Rural development Plan 2004-2006, Rural Development Programme 20072013, agrarian structure.

JEL Classification: Q1.

(C) The Author, 2018. This article is published with open access at Sumy State University.

\section{Introduction}

The term agrarian structure is a very broad concept. Over the last few decades, many definitions of agrarian structure have been made. At the beginning of the 20th century, attempts to define the agrarian structure were limited only to the recognition of the ownership structure of farms, however, the inclusion of farms due to their size and classification to specific area groups proved in practice insufficient. In the post-war period, during the agrarian reforms in the countryside, several new definitions of this concept were formed.

According to B. M. Wawrzyniak, the agrarian structure brings together the multiplicity of ownership relations and the principles of agricultural production organization, in conjunction with agricultural markets and the entire social and technical infrastructure. It informs about the principles of land trading, the size of farms as well as the legal and economic situation affects the position of the owner of the farm ${ }^{1}$.

According to A. Leopold, the agrarian structure is first of all the multitude of agricultural holdings measured by the usable land area. According to the author, to better describe the organization of agricultural space, it must be understood that agricultural holdings are also a human factor. This fact makes us look at the village as a habitat for the farming community ${ }^{2}$.

\footnotetext{
${ }^{1}$ Wawrzyniak B. M. (2004). Przemiany struktury agrarnej w rolnictwie polskim, Włocławek, str. 9.

${ }^{2}$ Leopold A. (1997). Rolnictwo w procesie przemian i rozwoju gospodarki, Warszawa, str. 69, 92.
} 
The concept of agrarian structure within the meaning of Community law and in the Western European nomenclature is understood much more broadly, namely as a set of factors affecting agricultural production, the level of producers' income and their productivity ${ }^{3}$.

\section{Factors shaping the agrarian structure}

Actions towards rural areas and agriculture can be divided into the following groups: price maintenance and stabilization of markets, subsidies to agricultural production means and subsidies for interest on purchase credits, structural policy in rural areas and agriculture.

Structural changes in rural areas and agriculture take place through the simultaneous operation of many different instruments. The first of them are ownership transformations in the agricultural sector after 1989.

They concern the areas of post-state farms, which consist in giving agricultural land primarily to lease, and partly also through the sale of land. Another is the additional interest rate for loans: for the purchase of agricultural land, creation or installation of a farm as part of a settlement program and for farmers before 40 years, implementation of agricultural and special operations, purchase of agricultural production resources, resumption of farms affected by natural disasters. The next instrument, which introduces changes in the agrarian structure, supports the creation of new jobs thanks to loans, micro-loans, guarantees and sureties. Other instruments are: afforestation of agricultural land, assistance in establishing agricultural producer groups, professional activation, non-returnable subsidies for investments in agricultural holdings and structural pensions for farmers.

The processes taking place in the period of political transformation in the early 1990s caused many changes in the Polish economy as well as in agriculture. They were connected both with the necessity of deep restructuring and modernization of the agricultural sector, as well as the need to improve social and economic cohesion and to mitigate the effects of civilization delays in rural areas. Just before Poland's accession to the European Union, the average area of farms in Poland was about 7 ha, while in the EU it exceeded 18 ha. This meant that with such a large agrarian difference, Polish farmers could not compete with large and well-organized farms from EU countries. Therefore, growing competition on the agricultural market forced an increase in the area of agricultural holdings.

\section{Structural pensions}

The system of structural pensions in Europe was known already in the 1960s. The earliest started to operate in France, when it operated in the form of agricultural pensions paid in the form of an annual salary for farmers who ceased to conduct agricultural activity regardless of "normal" pensions, the obtaining of which was conditional upon the transfer of the farm ${ }^{4}$.

Prior to joining the European Union in Poland, from January 1, 2002, the Act on structural pensions was in force. It set out the conditions for acquiring the right to a structural pension and the conditions imposed on farmers who take over a farm. Few people, however, benefited from structural pensions. This was because the statutory provisions required meeting a number of difficult joint conditions, for example: the structural pension could not be obtained by farmers with an area of less than 3 ha, the pension was not payable if one of the spouses running the farm did not meet the requirements to obtain it, even if the second one was fulfilled. The amount of the benefit was also not encouraging. The amount of the structural pension was equal to one and a half times the lowest pension; if both spouses were entitled to the benefit at the same time, each of them was entitled to a benefit in such amount ${ }^{5}$.

The 2001 Act was to play a significant role in structural changes in rural areas. In central and eastern Poland, and partly south-eastern Poland, the program was to mainly improve the surface structure of farms, while in north-eastern Poland the program was to have a greater impact on the change in the age structure than on the improvement of the surface structure. This conviction was related to the fact that in the north of Poland the average size of farms was 18 ha, while in the south less than $3 \mathrm{ha}^{6}$.

\footnotetext{
${ }^{3}$ Lichorowicz A. (1996). Problematyka struktur agrarnych w ustawodawstwie wspólnoty europejskiej, Kraków, str. 10.

${ }^{4}$ Trawiński K. (2001). Renty strukturalne $w$ rolnictwie. Służba Pracownicza nr 10, str. 7.

${ }^{5}$ Dziennik Ustaw (2001). nr 52, poz. 539.

${ }^{6}$ Dane Głównego Urzędu Statystycznego, Bank Danych Lokalnych.
} 
The system of structural pensions is one of many other activities carried out in Poland, the task of which was to change the agrarian structure of farms. The aim of implementing such a policy was activities whose implementation was to lead to stabilization of farmers' income sources and reconstruction of the structure of farms. Structural rent is a specific and temporary financial benefit granted to a farmer in pre-retirement age and paid only until the retirement age and after fulfilling certain conditions.

The basic aims of operation the structural pensions are:

$>$ providing income to farmers who give up agricultural activity in the pre-retirement age;

$>$ lowering the average age of people conducting agricultural activity (accelerating the process of generation replacement);

$>$ allocation of agricultural land for non-agricultural purposes in the case when agricultural activity cannot be carried out in satisfactoryeconomic conditions. Structural pensions are to encourage farmers in the preretirement age to transfer their farms in a way that improves the viability of farms in Poland and provide them with a sufficient source of income after cessation of this activity.

The system of structural pensions functioning in a given programming period differed from each other by the conditions whose fulfilment allowed for the possibility of applying for such aid. Differences between the conditions for granting structural pensions in the RDP (Rural Development Program) 2004-2006 and RDP (Rural Development Program) 2007-2013 are presented in the table below.

Table 1. Differences between the conditions for granting structural pensions in the RDP 2004-2006 and RDP 2007-2013

\begin{tabular}{|l|l|l|}
\hline \multirow{2}{*}{ Condition } & \multicolumn{2}{|c|}{ Programming period } \\
\cline { 2 - 3 } & \multicolumn{1}{|c|}{$2004-2006$} & \multicolumn{1}{c|}{$2007-2013$} \\
\hline $\begin{array}{l}\text { The age of the beneficiary to whom } \\
\text { the structural pension can be taken }\end{array}$ & 75 years & 65 years \\
\hline Height of the structural pension & $\begin{array}{l}210-440 \% \text { of the lowest pension } \\
\text { amount }\end{array}$ & $\begin{array}{l}150-250 \% \text { of the amount of the lowest } \\
\text { pension }\end{array}$ \\
\hline Surface transferred & minimum 1 ha & $\begin{array}{l}\text { minimum 3 ha (in addition to the following } \\
\text { provinces: Ślaskie, Małopolskie, } \\
\text { Podkarpackie, and Swiętokrzyskie) }\end{array}$ \\
\hline Forms of handing over the farm & sale, donation, lease & sale, donation \\
\hline
\end{tabular}

Source: Own study based on RDP 2004-2006 and RDP 2007-2013.

Structural pensions consist in creating attractive financial incentives for farmers in the pre-retirement age to definitively cease agricultural activity. The main objective of introducing structural pensions is to improve the area structure of agricultural holdings, while reducing the number of farms, as well as providing farmers who withdraw from agricultural activity with sources of income in the pre-retirement period. Thus, structural goals have been combined here, which involve stimulating desirable structural and demographic changes in Polish agriculture with no less important social goals ${ }^{7}$.

\section{Characteristics of the agrarian structure during the period of structural pensions}

Under the Rural Development Plan for the years 2004-2006, more support was granted as part of structural pensions. The greater number of pensions awarded in the years 2004-2006 resulted mainly from the smaller formal requirements that had to be met in order to receive the benefit and from a larger number of funds allocated for this purpose.

Due to the farmers' great interest in obtaining structural pensions under the RDP 2004-2006, in the RDP for the years 2007 - 2013, the Agency for Restructuring and Modernization of Agriculture has tightened the criteria for receiving pensions, which translated directly into fewer positive decisions awarding the pension. Data regarding the percentage of beneficiaries of structural pensions both under RDP 2004-2006 and RDP 2007-2013 are presented below.

\footnotetext{
7 Tomkiewicz E. (2002). Funkcje rent strukturalnych w procesie integracji polskiego rolnictwa z Unią Europejską. Oeconomia nr 1 - 2, Scientiorum Polonorum, Wyd. ACTA, Warszawa, str. 137 - 138.
} 


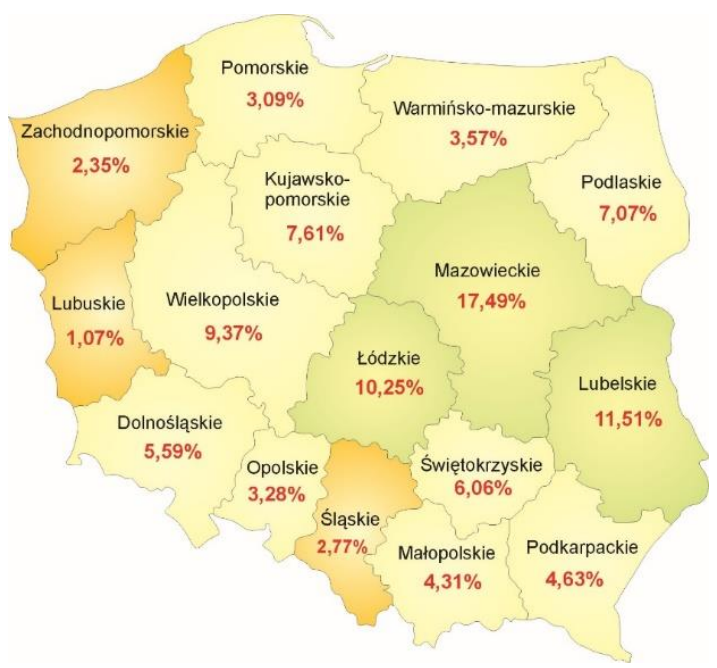

Source: own study based on ARMA data.

Figure 1. Beneficiaries of structural pensions divided into province (in\%)

Beneficiaries of structural pensions could transfer their farm: a successor, another farmer, to enlarge the farm, for afforestation or to protect nature. Afforestation and nature conservation were not very popular. Due to the low number of occurrences in the table below, these objectives were not taken into account, the focus was on expanding farms and handing over the successor. On the national scale, $49.7 \%$ of farms were transferred to successors, and $50.3 \%$ to enlarge another farm.

Table 2. Percentage of transferred farms by target in individual provinces (in\%)

\begin{tabular}{|l|c|c|}
\hline \multicolumn{1}{|c|}{ Province } & Successor & Enlarging the farm \\
\hline Dolnośląskie & 33,3 & 66,7 \\
\hline Kujawsko-pomorskie & 38,3 & 61,7 \\
\hline Lubelskie & 40,4 & 59,6 \\
\hline Lubuskie & 44,4 & 55,6 \\
\hline Lódzkie & 44,2 & 55,8 \\
\hline Małopolskie & 61,6 & 38,4 \\
\hline Mazowieckie & 43,7 & 56,3 \\
\hline Opolskie & 35,5 & 64,5 \\
\hline Podkarpackie & 55,7 & 44,3 \\
\hline Podlaskie & 39,0 & 61,0 \\
\hline Pomorskie & 40,1 & 59,9 \\
\hline Śląskie & 54,5 & 45,5 \\
\hline Świętokrzyskie & 49,9 & 50,1 \\
\hline Warmińsko-mazurskie & 36,3 & 63,7 \\
\hline Wielkopolskie & 53,4 & 46,6 \\
\hline Zachodniopomorskie & 35,3 & 64,7 \\
\hline Poland & 49,7 & 50,3 \\
\hline
\end{tabular}

Source: own study based on ARMA data.

The area change takes place in farms that have taken over the transferred farm to increase: in whole, or have obtained only a part of the farm from the farmer who has passed into a structural pension. Therefore, the farms transferred for enlargement directly influence the change in the agrarian structure. The average size of the farm given for this purpose in Poland was 10.71 ha. In the case of the farm of the transferee, the average size of the acquiring farm was 27.30 ha in the country. It is worth adding at this point that the average size of the farm of the transferred successor in Poland was 10.96 ha. There is no significant difference between the size of farms transferred for individual purposes, but farms transferred for the purpose of enlargement have more influence on the agrarian structure, as on average 10 ha transferred to enlargement significantly affects the size of existing units and thus contributes to the change of structure already existing. 
Table 3. Average size of the transferred farm within the framework of structural pensions of the successor and the enlargement of the holding broken down into voivodships (in ha)

\begin{tabular}{|l|c|c|}
\hline \multirow{2}{*}{ Province } & \multicolumn{2}{c|}{ Average size of the transferred holding } \\
\cline { 2 - 3 } & Successor & For enlargement \\
\hline Dolnośląskie & 11,24 & 12,26 \\
\hline Kujawsko-pomorskie & 14,24 & 8,87 \\
\hline Lubelskie & 9,54 & 14,51 \\
\hline Lubuskie & 12,83 & 9,46 \\
\hline Lódzkie & 10,01 & 4,65 \\
\hline Małopolskie & 4,65 & 10,01 \\
\hline Mazowieckie & 11,18 & 11,54 \\
\hline Opolskie & 12,48 & 4,59 \\
\hline Podkarpackie & 5,25 & 11,99 \\
\hline Podlaskie & 14,46 & 16,25 \\
\hline Pomorskie & 14,95 & 7,33 \\
\hline Śląskie & 6,81 & 6,55 \\
\hline Świętokrzyskie & 7,67 & 16,53 \\
\hline Warmińsko-mazurskie & 17,67 & 13,34 \\
\hline Wielkopolskie & 13,62 & 14,37 \\
\hline Zachodniopomorskie & 15,12 & 10,71 \\
\hline Poland & 10,96 & \\
\hline
\end{tabular}

Source: own study based on ARMA data.

Over the years, the number of small farms has decreased and the number of large farms has increased. From year to year, the average size of an agricultural holding is also systematically increasing. The system of structural pensions also accelerated generational renewal. As a result, farms were taken over by younger people who had agricultural education. The number of individual farms above 1 hectare is also systematically decreasing (see table below).

Table 4. Individual farms over 1 ha of UAA in 2004 and 2016 (in ha)

\begin{tabular}{|l|c|c|c|}
\hline \multirow{2}{*}{ Province } & \multicolumn{2}{c|}{ Number of individual farms over 1 ha of UAA } & \multirow{2}{*}{ Difference (in\%) } \\
\cline { 2 - 3 } & 2004 & 2016 & 73,94 \\
\hline Dolnośląskie & 210197 & 54786 & 66,65 \\
\hline Kujawsko - pomorskie & 188395 & 62835 & 64,36 \\
\hline Lubelskie & 501954 & 178910 & 77,47 \\
\hline Lubuskie & 87575 & 19733 & 66,50 \\
\hline Lódzkie & 364061 & 121976 & 76,03 \\
\hline Małopolskie & 575083 & 137849 & 66,76 \\
\hline Mazowieckie & 637392 & 211890 & 75,22 \\
\hline Opolskie & 105985 & 26260 & 73,71 \\
\hline Podkarpackie & 493164 & 129648 & 61,92 \\
\hline Podlaskie & 210960 & 80335 & 69,22 \\
\hline Pomorskie & 123879 & 38131 & 84,74 \\
\hline Śląskie & 338722 & 51678 & 70,46 \\
\hline Świętokrzyskie & 282103 & 83340 & 66,83 \\
\hline Warmińsko - mazurskie & 127480 & 42289 & 63,64 \\
\hline Wielkopolskie & 327098 & 118938 & 75,26 \\
\hline Zachodniopomorskie & 117393 & 29038 & 70,42 \\
\hline Poland & 4691441 & 1387936 & \\
\hline
\end{tabular}

Source: own study based on BDL GUS data and Central Statistical Office, Statistical Yearbook of Agriculture 2016, Warsaw 2017. 
Referring to the data presented above, it can be concluded that the system of structural pensions fulfilled its fundamental assumption and influenced the improvement of the agrarian structure. At the same time, he contributed to generational change in Polish farms.

\section{Conclusions}

The aim of the work is an attempt to assess the implementation of the structural pensions scheme for farmers. In Poland, this task was implemented as part of the Rural Development Plan 2004-2006 and the Rural Development Program 2007-2013. In the new EU perspective for the years 2014-2020, this action is no longer implemented, but funds for the payment of structural pensions granted in an earlier period are still paid out. The idea behind structural pensions is to encourage farmers to stop farming activities in the pre-retirement age and transfer their farms in a way that improves the country's agrarian structure. Taking into account the indicators regarding the implementation of the program, it can be concluded that early retirement for farmers has significantly contributed to the acceleration of the generational replacement process among farmers.

\section{References}

1. Baborska B. (2006), Kontrowersje wokót reformy wspólnej polityki rolnej Unii Europejskiej (The controversy over the reform of the common agricultural policy of the European Union). Zakres i formy interwencjonizmu państwowego we współczesnych systemach gospodarczych, pod red. D. Kopycińskiej, Szczecin.

2. Halamska M. (2006), Renty strukturalne a przemiany polskiej wsi. Uwagi socjologa (Framer's pensions and changes in the Polish countryside. Notes of a sociologist). Wieś i Rolnictwo, nr 2(131).

3. Klimczak B., Olszewski L., Pisz Z. (1999), Integracja europejska: transformacja systemowa w Polsce, procesy dostosowawcze (European integration: systemic transformation in Poland, adjustment processes), Wrocław.

4. Leopold A. (1997): Rolnictwo w procesie przemian i rozwoju gospodarki (Agriculture in the process of changes and development of the economy), Warszawa.

5. Lichorowicz A. (1996): Problematyka struktur agrarnych w ustawodawstwie wspólnoty europejskiej (Problems of agrarian structures in the legislation of the european community), Kraków.

6. Otoliński E. (2007), Przemiany w strukturze agrarnej w Polsce poludniowej w latach 1996-2005 (Transformations in the agrarian structure in southern Poland in 1996-2005). Roczniki Naukowe Stowarzyszenia Ekonomistów Rolnictwa i Agrobiznesu, t. IX, z. 1, Warszawa -Poznań -Kraków.

7. Paszkowski S. (2002), Prawne aspekty funkcjonowania wcześniejszych emerytur rolniczych w Unii Europejskiej (Legal aspects of the functioning of earlier agricultural pensions in the European Union). Ubezpieczenia społeczne. Wieś i rolnictwo, pod red. M. Adamowicza, Warszawa.

8. Rudnicki H. (2005), Przemiany strukturalne w polskim rolnictwie w okresie transformacji systemowej (Agricultural reforms in Poland in the period between and post-war). Kwestia agrarna w Polsce i na świecie, Warszawa.

9. Sikorska-Wolak I. (2007), Renty strukturalne szansa na przyśpieszenie wymiany pokoleń w rolnictwie polskim (Framer's pensions as an opportunity to accelerate the generation exchange in Polish agriculture), Stowarzyszenie Ekonomistów Rolnictwa i Agrobiznesu. Roczniki Naukowe, t. VIII, z. 4, Warszawa.

10. Statistical Yearbook of Agriculture 2016, Warsaw 2017.

11. Szemberg A. (1995), Przemiany agrarne w chtopskim rolnictwie (wyniki sondażu z 1994 r.)( Agrarian transformations in peasant agriculture (results of a survey from 1994). Instytut Ekonomiki Rolnictwa i Gospodarki Żywnościowej, nr 79, Warszawa.

12. Tomkiewicz E. (2002): Funkcje rent strukturalnych w procesie integracji polskiego rolnictwa z Unia Europejska (Functions of framer's pensions in the process of integration of Polish agriculture with the European Union). Oeconomia nr $1-2$, Scientiorum Polonorum, ACTA, Warszawa.

13. Trawiński K. (2001), Renty strukturalne w rolnictwie (Framer's pensions in agriculture). Służba Pracownicza $\mathrm{nr} 10$.

14. Wawrzyniak B. M. (2004): Przemiany struktury agrarnej w rolnictwie polskim (Transformation of the agrarian structure in polish agriculture), Włocławek.

15. Ziętara W. (2005), Reformy rolne w Polsce w okresie między i powojennym (Agricultural reforms in Poland in the period between and post-war). Kwestia agrarna w Polsce i na świecie, Warszawa 2005.

16. Dziennik Ustaw (Journal of Laws of the Republic of Poland) (2001) nr 52, poz. 539.

17. Own study based on BDL GUS data, Central Statistical Office, ARMA data. 